\title{
The Media and the Configuration of "Mental Maps": Their Relation to Institutional Homogenization among University Students and Disciplina Entities
}

\author{
Dra. Miriam Aparicio \\ National Council of Scientific Research (CONICET). Argentina. \\ E-mail: miriamapar@yahoo.com
}

Doi:10.5901/mjss.2013.v4n11p235

\section{Abstract}

This study tests some hypotheses included in the psycho-socio-communicational paradigm, which emphasizes the long term cognitive effects of the media and the role of the psychosocial subject as recipient: the hypothesis of "agenda-setting" (McCombs \& Shaw, 1976). The four main objectives were: to elucidate the cognitive effects of the media in university graduates; to detect levels of manipulation and homogenization of their "mental maps"; to ascertain the personality factors that condition differential receptivity ("Filtering" of the news) (151 variables); to determine the degree of impact and incidence of the press in the public's mental patterns and in the university identities. The sample was made up of $(N=516)$ graduates from Cuyo University (Argentina). Quanti-qualitative techniques were complemented: semi-structured survey and interviews). The incidence of psychology and education in the differential construction of "cognitive maps" was confirmed as well as the stronger incidence of the press as regards the impact caused by news and the mental homogenization.

Keywords: Media, Education, Psychology

\section{Introduction}

This study tests hypotheses included in the psycho-socio-communicational paradigm, which emphasizes the long term cognitive effects of the media and the role of the psychosocial subject as recipient: the hypothesis of "agenda-setting".

The primary objetives were:

1. To elucidate such effects in audiences with different levels of education,

2. To detect levels of manipulation and homogenization of the "mental maps" linked with the centralization of the "fourth power",

3. To ascertain personality factors which condition differential receptivity of the addressees ("filter" of the news) related to the socio-evaluative context.

Two lines interest us: the first emphasizes the effects of the media according to individual psychology, and the second, centered on different parameters linked with psychosocial characteristics of the youths and the messages.

Finally, the central hypotheses are offered, taking into account that forty nine were considered:

1. there would be a marked correlation between the order of importance assigned to the information by the media and that adopted by youths (high incidence of "mental construing"),

2. receptivity of the addressees would vary according to cognitive competence;

3. certain psychological characteristics would render the subject less impressionable to media influence.

\section{Method}

\subsection{Sample}

The sample was made up of graduates ( $N=516)$ and drop-outs $(\mathrm{N}=2157)$ from eighteen careers in Cuyo University (Argentina) between 1980-1993; research work that has been carried out to date. The sampling was stratified and the start, random, confidence interval was taken at $95 \%$ and error margin at $4 \%$.

\subsection{Instruments}

Quanti-qualitative techniques were complemented: semi structured survey, in-depth interviews, life stories and anecdote 
accounts. Also, tests were applied in order to observe the behavior of certain psychosocial variables (such as control locus, stress, aggressiveness, self-esteem). Some of these tests (such as Rotter, CEP, Maudsley's Inventory have been validated here by the author. The analysis was made in two instances: products and processes.

\subsection{Procedure}

1. Survey of data in files over ten years old.

2. Implementation of the aforementioned techniques. Being a vertical assessment, the follow-up was carried out private addresses, as graduates and drop-outs were no longer in the educational system.

3. The survey of both agendas (those of the media and of the public), setting up of the time frame, took into account the models of the agenda/effect: awareness, relevance and priorities (Becker, Mc Coombs, Mc Leod). Graphic media was also used (six representative national newspapers, displaying different "ideologies"), as well as visual media (television newsreels). The comparison procedure for both agendas and analytical strategy are original.

The range of variables was very wide $(\mathrm{N}=151)$, covering psychological, base line, pedagogic/institutional, structural an communicational aspects. Finally, hypotheses and results were compared. The methodological options made it possible to analyze the psychological dimension related to the life stories and academic aptitude measurements. The effects of the intervening variables were recognized by means of discerning interpretation.

\section{Results}

1. Hypotheses concerning Social, Cognitive and Media Psychology were corroborated.

2. The agenda/effect is observed: youths consider relevant only whatever is so for the media. The remaining information is not recovered nor is able to access the "cognitive maps".

3. A high homogenization of thought in thus confirmed, as a result of the homogenization of news (incremented in quantity by of unified quality).

4. Nevertheless, it is interesting to point out that the strengthening of a certain image of reality is not found in the same for all, not every time, depending on the conjugation of different factors among which education and personality act as decisive filters. In addition, the different readings that can be done in the different programs reveal disciplinary and institutional identities. Results show different interpretations and levels of "filtering" in accordance with self-esteem, control locus, n-ach, fatalism, valuations, stress, apathy, prejudices, among other variables.

\section{Conclusion}

There is a common axis to the hypotheses on agendas "...nous disent non pas qu'il faut penser, mais a quoi il faut penser", which impinges clearly on our "mental maps". This fact constitutes a source of concern if attention is paid to the uncritical dazzling which the new language prevailingly elicits.

This constitutes a challenge to those who must prepare for a responsible interpretation of images ("visual literacy"). For psychologists, the findings suggest a revision of the task for this, the era of the image.

\section{References}

Aparicio, M. (1997). Sobre efectos de los media: una investigación sobre hipótesis de la agenda-setting. Investigaciones en Sociología, 6, 35-58.

Aparicio, M. (2001). ¿Qué transformaciones se operan en los públicos a partir de la imagen de sociedad que hoy ofertan los medios? Un análisis desde la psicología social de la comunicación. Enfoques, 13, 1-2, 41-51.

Becker, L; McCombs, M \& J. McLeod (1975). The Development of Political Cognitions. Political Communication, Beverly Hills: Sage, 2164.

Bregman, D. \& Missika, J. (1987). On framing the campaing: mass media roles in negociating the meaning of the vote. European Journal of Communication, 2.

Bregman, D. \& Missika, R. (1989). La fonction d'agenda: une problématique en devenir. Hermes, 4, 17-24.

Cherkaoui, M. (1979). Les paradoxes de la réussite scolaire. Paris: PUF.

Cobb R. \& Elder, C. (1971). The Politics of Agenda-Building: An Alternative Perspective for Modern Democratic Theory. The Journal of Politics, 33, 897-915. 
Cohen, B.C. (1963). The press and Foreign Policy. Princeton: Princeton University Press.

Cook, F., Tyler, T., Goetz, E., Gordon, M., Protess, D., Leff, D. \& Molotch, H. (1983). Media and Agenda-Setting: Effects on the Public, Interest Group Leaders, Policy Makers and Policy. Public Opinion Quaterly, 47, 16-35.

Eco, U. \& Fabbri, P. (1978). Progetto di ricerca sull'utilizzazione dell'informazione ambientale. Problemi dell'informazione, 4, 555-597.

Erbring, L., Goldenberg, E. \& Miller, A. (1980). Front-Page News and Real-World Cues: A New Look at Agenda-Setting by the Media. American Journal of Political Science, 24(1), 16-49.

Escarpit, R. (1976). Théorie générale de l'information et de la communication. Paris: Hachette.

Ettema, J. \& Cline, F. (1977). Deficits, Differences and Ceilings: Contingent Conditions for Understanding the Knowledge Gap. Communication Research, 4, 39-47.

Eyal, C. Winter, J. \& De George, W. (1981). The Concept of Time Frame in Agenda-Setting. Mass Communication Review Yearbook, 2 , 212-217.

Gerbner, G. \& Gross, L. (1976). Living with Television: The Violence Profile. Journal of Communication, spring, 18-24.

Hall, S. (1980). Cultural Studies: Two Paradigms. Media, Culture and Society, 2, 57-72.

Hovland, C., Harvey, O. \& Sheriff, M. (1957). Assimilation and Contrast Effects in Reaction to Communication and Attitude Change. Journal of Abnormal and Social Psychology 40 2, 244-252.

Hovland, C. \& Weiss, W. (1949). The Influence of Source Credibility on Communication Effectiveness. Public Opinion Quaterly 15(4), 635-650.

lyengar, S. (1979). Television News and Issue Salience: A Reexamination of the Agenda-Setting Hypothesis. American Politics Quaterly, 7, 4, 395-416.

Lasswell, H. (1936). Politics: Who Gets What, When,Hhow. New York: McGraw Hill.

Lazarfeld, P. (1941). Remarks on Administrative and Critical Communications Research. Studies in philosophy and social science,9, 1 ,2-16.

Le Bon, G. (1983). Psicología de las masas. Madrid: Morata.

Mancini, P. \& Wolf, M. (1990). Mass Media Research in Italy: Culture and Politics. European Journal of Communication, 5, $28-42$.

Mc Clure, R. \& Patterson, T. (1976). Print vs. Network News. Journal of Communications, 26(2), 23-28.

Mc Combs, E. (1981). Setting the Agenda for the Agenda-Setting Research. An Assessment of the Priority Ideas and Problems. Mass Communication Review Yearbook, 2, 209-211.

Mc Combs E. \& Shaw, D. (1972). The Agenda-Setting Function of Mass Media. Public Opinion Quaterly, 36, $176-187$.

McKuen, M. \& Coombs, S. (1981). More than News. Media Power in Public Affairs. Beverly Hill: Sage.

McLeod, J., Becker, L. \& Byrnes, J. (1974). Another Look at the Agenda-Setting Function of the Press. Communication Research, 1, 2, 131-166.

Neumann, N. (1973). Returns to the Concept of Powerful Mass Media. Studies of Broadcasting, 9, 67-112.

Neumann, N. (1983). The Effect of Media on Media Effects Research. Journal of Commmunication, 33,3, 157-165.

Pasquier, D. (1994). Vingt ans de recherches sur la télévision. Sociologie du Travail, 34, 63-85.

Patterson, T. (1980). The role of Mass Media in Presidential Campaings: The Lesson of 1976. Items, 2, 25-30.

Rimoldi, H. (1997). Información y cognición e información y creatividad. Psicopedagógica, 2 2, 11-27.

Rimoldi, H. (1999b). Información y cognición e información y creatividad. Boletín de la Academia Nacional de Medicina, 40, 10-14.

Roberts, D. (1972). The Nature of Communication Effects. En W. Schramm \& D. Roberts (Eds.), The process and effects of mass communication. Chicago: University of Illinois Press.

Shaw, E. (1979). Agenda-Setting and Mass Communication Theory. International Journal for Mass Communication Studies, 25, 2, 96105.

Wolf, M. (1987). La investigación en la comunicación de masas. Buenos Aires: Paidós.

Zucker, H. (1978). The Variable Nature of New Media Influence. Communication Yearbook, 2, 225-240. 